\title{
When is Green Really Green? A Latvian Case Study on Updating of Food Supply Green Public Procurement
}

\author{
Jana SIMANOVSKA ${ }^{1 *}$, Inese PELSA ${ }^{2}$, Nora KIBILDA-KINNA ${ }^{3}$ \\ ${ }^{1}$ Vidzeme University of Applied Sciences, Cēsu iela 4, Valmiera, LV-4201, Latvia \\ ${ }^{2,3}$ University of Latvia, Raina bulvāris 19, Riga, LV-1586, Latvia
}

\begin{abstract}
Green public procurement (GPP) is an important tool and is used to reduce adverse environmental impacts caused by food production. To have a more detailed look at the application of GPP in Latvia, the authors screened 97 public tenders for supply of food products, documenting the choice of the green criteria. Only $15 \%$ of the screened tender documents corresponded to the national GPP requirements. Only $4 \%$ of the tender documents gave higher priority exclusively for organic products compared to products within national quality schemes or integrated pest management agriculture. The authors compared these findings with the opinions of environmental experts, GPP guidelines by the European Commission, and experience from other countries. The authors conclude that 1) selfreporting is not an appropriate method to measure the implementation level of GPP, and 2) having a large number of criteria without clear goals can lead to using the easiest, but least environmentally beneficial options, and 3) for some tenders complying with national GPP, the environmental benefits may be unclear.
\end{abstract}

Keywords - Case study Latvia; environmental criteria; food production; green public procurement; local government; organic products

\section{INTRODUCTION}

\subsection{Green Public Procurement as a Tool to Reduce Environmental Impacts of Food Production}

Food production to feed more than seven billion people causes much of the adverse environmental impact caused by human activity. From agricultural production to retail, the provision of food causes $26 \%$ of anthropogenic greenhouse gas emissions, creates ca. $32 \%$ of global terrestrial acidification, and ca. $78 \%$ of eutrophication [1]. Agricultural production, through these emissions and also by using wilderness for growing food, is an important cause for rapid loss of biodiversity that is also fuelled by the exorbitant use of toxic substances e.g. agricultural pesticides. According to data from the Food and Agriculture Organization of the United Nations, $2.6 \mathrm{~kg}$ of active substances of pesticides per ha of cropland or more than 4 million tons totally were used globally in 2017 [2], and this poses a threat for people who live nearby. Recognizing the high impact on the environment, the importance of greening the food sector is addressed by the Sustainable Development Goals of the United Nations. An

\footnotetext{
* Corresponding author.

E-mail address: jana.simanovska@me.com 
important tool to achieve this is the use of green public procurement - an approach where state authorities and municipalities procure products and services considering environmental impacts throughout the production life cycle with an aim to choose products and services that reduce adverse environmental impacts. Thus, state and local authorities can use their purchasing power to stimulate the market to offer products with lower environmental impacts. For example, in 2014, public procurement in the European Union reached $19 \%$ of gross domestic product [3], which is an important market share to influence market actors. Scholars and policy developers agree that public procurement can be used as a tool to stimulate economic growth and address social challenges [4], [5]. Green public procurement, by adding criteria besides price, opens the opportunity for public authorities to promote better social, health, and environmental conditions [6], [7].

Recognizing the impact of public procurement, the European Union, starting with 2003, set requirements for Green Public Procurement (further on GPP) to encourage Member States to promote GPP, which would promote sustainable consumption and sustainable production patterns [8], and set a target that in $201050 \%$ of all public tenders be green.

\section{TABLE 1. GReEN Public Procurement Criteria For FoOd Products}

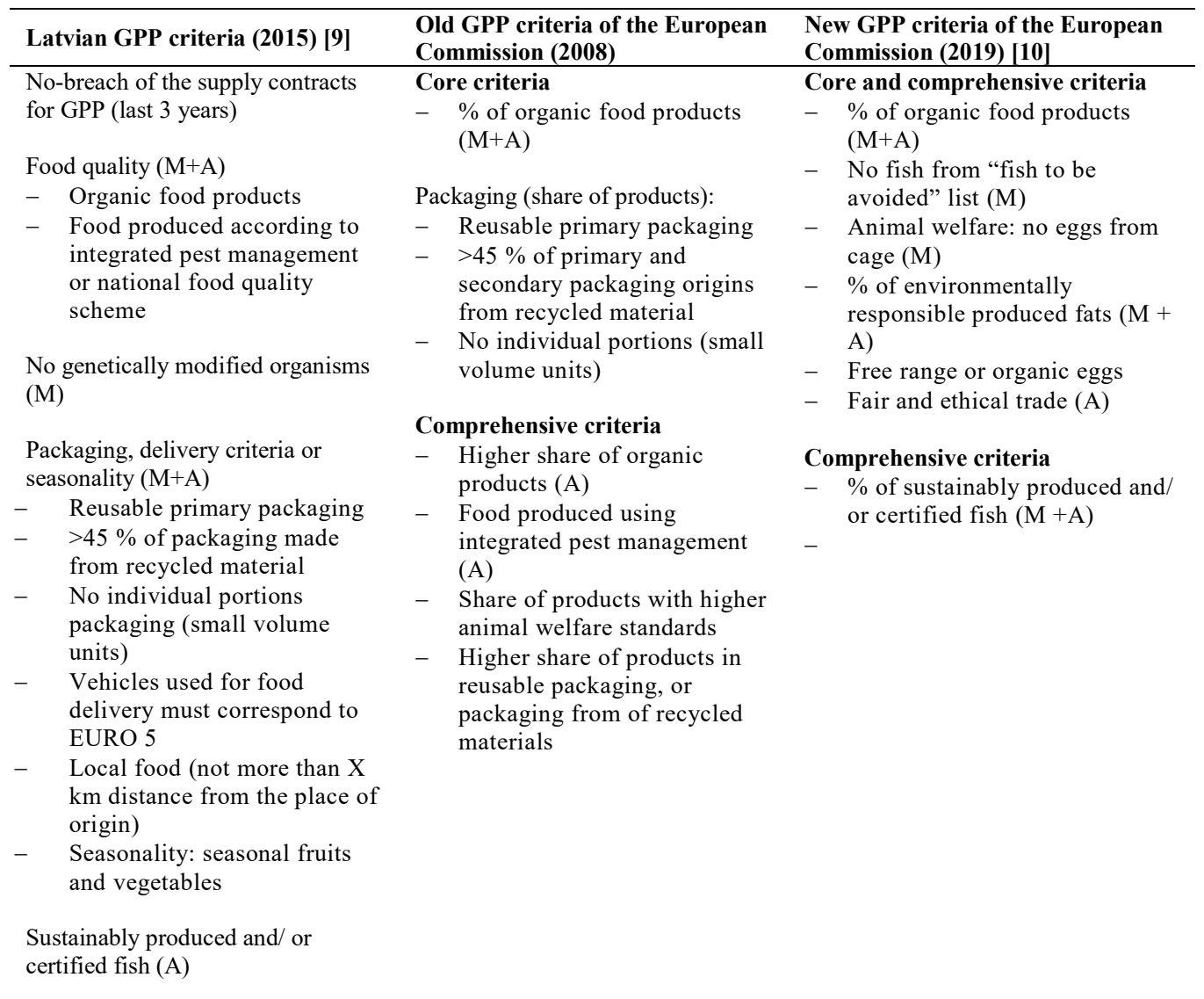

M: mandatory criteria; A: award criteria; $\mathrm{M}+\mathrm{A}$ : applicable twice; minimum share (\%) is set as mandatory, higher share can be required if outweighs price 
In 2008, the European Commission published GPP guidelines for food products and catering services, differentiating between core and comprehensive criteria. Core criteria address the most important environmental aspects by implementing affordable costs for companies and easy verification means for authorities. Core criteria are regarded as the benchmark for GPP [11]. Comprehensive criteria address wider aspects for more environmentally ambitious procurers (see Table 1). One distinguishes between two types of criteria: mandatory criteria must be met if the bidder is awarded the contract. Award criteria are applied in cases where the procurer seeks the most economically advantageous offer. They apply a weighted process, where various criteria including price are weighted and compared. Thus, if green award criteria cannot outweigh the price, and are not included in the procurement contract, use of nominally green award criteria, in practice, may not result in the most environmentally beneficial purchase.

In 2019, the European Commission published reviewed criteria for food products and catering services [10]. Some of the previous criteria were omitted because there was insufficient evidence of their environmental benefit (products from integrated pest management schemes) or were subject to overly complicated verification (criteria related to packaging) [11]. However, the share of organic products is part of the core criteria in both of the EU GPP criteria documents e.g. from 2008, and 2019.

\subsection{Development of GPP in Latvia}

Following the developments in the EU, the Latvian government issued the regulation "Requirements on application of environmental criteria for supply of food products and catering services" in 2014 and this made application of green criteria procurement mandatory from 2017. Later the regulation was replaced by a new regulation [9]. National GPP criteria are summarized in Table 1.

In 2015, the Latvian government adopted the Green Procurement Promotion Plan for 2015-2017 aiming to achieve that $15 \%$ of tenders (in financial terms) of all public tenders were GPP in 2015, and $20 \%$ in 2016, and $30 \%$ in 2017 respectively. Although these targets were lower than the EU wide target $(50 \%)$, they can be regarded as ambitious for a country that is just starting its GPP approach.

Compliance with national regulation on GPP in Latvia for food products can be achieved in two ways. First, if the lower price principle is applied, all criteria in the national GPP regulation should be included in the tender. Second, if the economically advantageous principle is applied, parallel to price criterion, the procurer should choose one criterion from each of the following criterion groups:

1. From food quality (organic or integrated pest management, or national food quality scheme);

2. No GMO;

3. Packaging, delivery or seasonality criteria group.

This means that a procurement that fully complies with Latvian national GPP criteria for food products, can be noncompliant with EU core criteria $(2008,2019)$, e.g. it might not include organic food.

\subsection{Assessment of Implementation of GPP}

Measurement of policy success is an important instrument in policy development. A European wide study on GPP uptake concluded that in 2010 only $26 \%$ of all contracts screened in the study could be considered "green" [12] although the objective was $50 \%$. 
According to national rules, all public procurements of food products should be compliant with national GPP criteria. In 2017, according to self-reports to the Procurement Monitoring Bureau, $54 \%$ of all tenders of food products and $79 \%$ of catering services were marked as GPP tenders. In $2018,90 \%$ of all tenders for food products and $99 \%$ of catering services were self-marked as GPP tenders. But is self-reporting sufficient to assess the implementation level of GPP?

With this research, the authors wanted to investigate which green public procurement criteria are applied for purchasing of food products and how they comply with national GPP regulation. When starting the work, authors put forward two research questions: 1) does self-reporting provide a true picture of green public procurement implementation and 2) does compliance with national GPP requirements lead to environmentally beneficial tenders?

The research reveals that only $15 \%$ of the tenders comply with national GPP requirements; despite a much higher number in self-reporting, but only $4 \%$ of published and screened tenders include purchase of organic food as mandatory, and only $1 \%$ include use of organic food as award criterion.

\section{Methods}

To gauge the uptake of the GPP criteria, the authors used information published in the database of the Procurement Monitoring Bureau of the Republic of Latvia. The database compiles all announcements of public tenders and collects the tender documentation for food products for educational bodies available online from webpages of the local authorities. The authors screened tenders that were published in the period from 01.07.2017 up to 01.07.2018; a total of 97 publications. Part of them authors excluded from further analysis because they lacked online documentation or were failed tenders with no result. In total, the authors analysed 73 tenders for food supplies. The authors screened the criteria applied and checked if the means of verification were sufficient. A limitation of this method is that this research does not provide information regarding how often the application of most economically advantageous principle favoured the green award criteria over price and appeared in the procurement contracts. Screening of procurement contracts would be a better method, but they are often not publicly available because of confidentiality. Another limitation is the probability that a green tender and a contract does not lead to a green purchase in case there is no control of whether the supplies comply with criteria.

In case of multiple criteria, the weighing by experts is sometimes applied as a method to determine the importance of a criterion [13]. To understand the environmental benefits of the criteria applied in the national GPP regulation, the authors polled 10 Latvian experts working on practical implementation of GPP. The experts were asked to judge the environmental importance and efficiency of the criteria included in the national regulation on a scale from one (least) to five (most). The experts were 5 male and 5 female, all with higher education, working in the environmental protection area from 5 to more than 21 years, $50 \%$ of them are also educated in environmental sciences.

\section{ReSUlts AND Discussion}

All public tenders for food products evaluated in this research applied the economically advantageous principle e.g. chose to use the mandatory criteria together with the award criteria. In this case, to comply with the national GPP rules, they needed to include at least 3 
criteria, e.g. one from each of the specific groups. Most of the tenders included only one mandatory criterion, see Fig. 1.

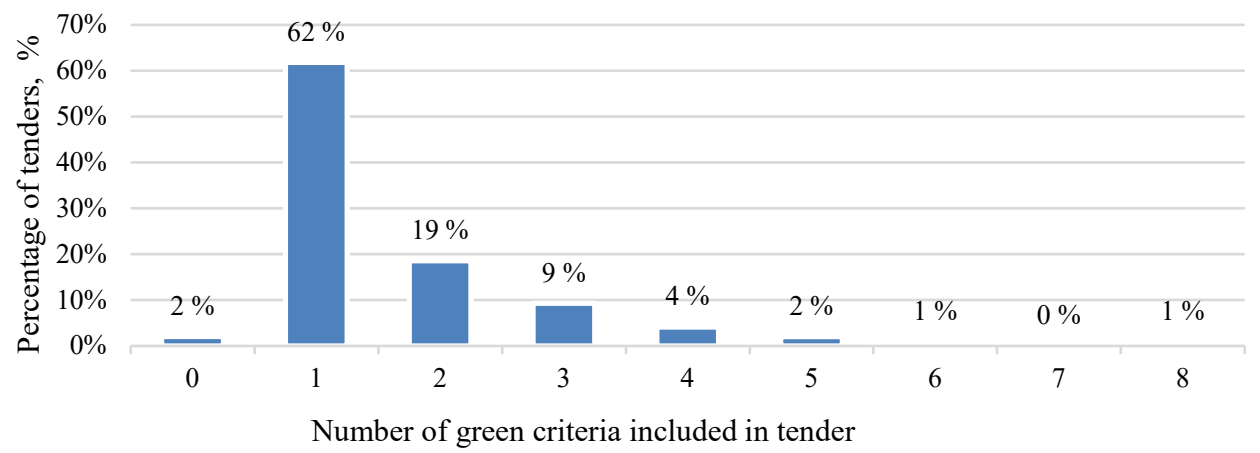

Fig. 1. Number of mandatory green criteria included in Latvian public tenders of food supply.

Looking at the criteria used, the most frequently applied criterion is "no GMO" and that might be explained by legislative requirements for food standards used by educational bodies e.g., Regulations Nr. 172 by Cabinet of Ministers. The next most frequently used mandatory criterion is "no breach of the supply contracts for GPP (during the last 3 years)". However, this criterion exceeds the power delegated by the Law on Public Procurement, which allows excluding bidders only for breaches that occurred in the last 12-month period and might be omitted from the regulations in the next review time.

The mandatory criteria from the "food quality" group were applied in $28 \%$ of tenders; only $4 \%$ of the tender documents included use of exclusively organic food. Mostly, from the group "food quality", the tenders chose the food produced according to integrated pest management schemes (further on IPM) or national food quality schemes, or grouped all three types of food production, which makes supply of organic food less probable because it is more expensive.

One frequently used criterion that was out of scope of national GPP legislation is requiring the supplier to take back used packaging (mandatory $6 \%$, award $28 \%$ ). The Latvian Public Procurement Law allows public bodies develop their own green criteria, and this could indicate that a sufficient number of suppliers are ready to offer such service. It should be noted that according to the waste legislation this requirement could be executed by suppliers only for packaging that does not "enter" the waste phase e.g. is used several times, otherwise the supplier should sub-contract to a waste management company.

Apart from the price, the most frequently used award criteria for evaluating the economic advantageous offer are criteria from product quality group (73\%) and distance from origin (71 \%) e.g. local food. In conclusion, only $15 \%$ of the tender documents contained at least one mandatory criterion from all three criteria groups. Thus, they were compliant with national GPP rules. However, a deeper look suggests that in the practice compliance may be even lower. The evaluation of the criteria and means of verification revealed that criteria are formulated insufficiently precisely: the proportion of clearly formulated criteria varies from $20 \%$ to $100 \%$ for different criteria. For example, requirements might be formulated in the form of a wish - "desirable", "preferred". A frequently misunderstood criterion is regarding local food e.g. specifying the distance from the "place of origin". Only $6 \%$ of the screened tenders applying this criterion gave a sufficiently clear formulation as "distance from origin of production". 
TABLE 2. FREQUENCY OF THE GPP APPLICATION IN THE FoOD TENDERS

\begin{tabular}{|c|c|c|c|}
\hline \multirow{2}{*}{ Criterion } & \multicolumn{2}{|c|}{$\begin{array}{l}\text { Frequency applied in the procurement } \\
\text { tenders }\end{array}$} & \multirow{2}{*}{$\begin{array}{l}\text { Medium score by } \\
\text { experts and range }\end{array}$} \\
\hline & Mandatory criteria & Award criteria & \\
\hline \multicolumn{4}{|l|}{ Selection: } \\
\hline $\begin{array}{l}\text { No-breach of supply contracts for GPP } \\
\text { (during the last } 3 \text { years) }\end{array}$ & $84 \%$ & & $3.4(5-1)$ \\
\hline \multicolumn{4}{|l|}{ 1. Food quality } \\
\hline Organic food products & $4 \%$ & $1 \%$ & $4.4(5-3)$ \\
\hline $\begin{array}{l}\text { Food produced according to IPM or } \\
\text { national food quality scheme }\end{array}$ & $22 \%$ & $27 \%$ & $2.9(4-1)$ \\
\hline $\begin{array}{l}\text { Food produced organic + IPM or } \\
\text { national food quality scheme }\end{array}$ & $32 \%$ & $73 \%$ & \\
\hline 2. No genetically modified organisms & $97 \%$ & $0 \%$ & $3.5(5-2)$ \\
\hline \multicolumn{4}{|l|}{ 3. Packaging, delivery, seasonality } \\
\hline Reusable primary packaging & $7 \%$ & $6 \%$ & $3.8(5-2)$ \\
\hline $\begin{array}{l}>45 \% \text { recycled material for secondary } \\
\text { and / or transport packaging }\end{array}$ & $4 \%$ & $0 \%$ & $3.6(5-2)$ \\
\hline No individual portions (unit packets) & $3 \%$ & $1 \%$ & $3.8(5-2)$ \\
\hline $\begin{array}{l}\text { Vehicles used for food delivery must } \\
\text { correspond to EURO } 5 \text { standard or } \\
\text { above }\end{array}$ & $10 \%$ & $7 \%$ & $3.7(5-2)$ \\
\hline $\begin{array}{l}\text { Local food (specified distance from the } \\
\text { place of origin) }\end{array}$ & $5 \% * *$ & $71 \% * * *$ & $4.0(5-1)$ \\
\hline $\begin{array}{l}\text { Seasonal deliveries for fruits and } \\
\text { vegetables }\end{array}$ & $13 \%$ & $0 \%$ & $4.2(5-1)$ \\
\hline $\begin{array}{l}\text { Sustainably produced and/ or certified } \\
\text { fish (A) }\end{array}$ & $0 \%$ & $0 \%$ & \\
\hline
\end{tabular}

* The lowest and the highest score given by experts

**IPM and national food quality scheme was merged due to very similar standards

***When organic food was mentioned with IPM and national food quality, we assumed that organic food will not be offered because it is more expensive

In other cases, it was not specified from which point the distance is measured, or the criterion allowed both: distance from a production site or a warehouse. That might lead to a situation, where in practice, even fewer supplies correspond to national GPP requirements. One drawback of the methodology used here is that we could not evaluate the quantitative impact of the criteria: e.g. procurement is often split in several lots, and different criteria might be applied to each lot. Thus, even if the GPP criteria are fully applied, they could affect a small amount of supplies. The authors think, that for better monitoring of GPP implementation level quantitative indicators (e.g. \% of total organic supplies in mass of monetary volume) should be included in the tenders and collected on regular basis by the suppliers or the procurers.

In order to evaluate the efficiency of the GPP in presence of several indicators, the authors asked environmental experts to judge the importance and efficacy of the criteria applied. Their evaluation (see Table 2) varied widely. The highest score, however, was received by organic food and that is a criterion that was seldom seen in the screened Latvian tenders. By contrast, the lowest scores were given to criteria that were most frequently used: i.e. from point of view 
of the questioned experts not the most important and efficacious criteria were used, although their individual views differ a lot. The cause might be the large number of criteria: without clear guidance of their importance there can be situations where the easiest and not the most important criteria are used.

This applies especially to the low uptake of organic food (only $4 \%$ of tenders used it as mandatory, $1 \%$ as award criterion). "Organic food" is one of the core EU GPP criteria, since it helps to reach several aims (reduce eutrophication, less toxic substances, higher animal welfare). The Latvian uptake of organic food in GPP is much lower than the European average reported a few years ago - in an EU-wide study performed in 2012, $34 \%$ of the studied public tender contracts for food and catering services included requirements for a share of organic food [12].

One of the barriers for higher uptake of organic food is its higher price, as many scholars agree [14]. Latvian school meals are partly subsidised by the state (1.42 euros per person), and local municipalities might not want to increase their own share to cover the rising costs of school meals if there were a higher share of more expensive organic products. Also, supply shortages can play a role: according to data from the Association of the Latvian Organic Agriculture, organic produce covers only $2 \%$ of the total national food market [15]. However, it is noticeable that the criterion "organic food" is extremely seldom used as an award criterion to enable weighting against price and availability when looking for the most economically advantageous offer. The result is a hamster wheel: organic products are not included because of unstable supply, but their production does not increase because of unstable demand.

Also, a lack of a general understanding of the concept "organic food", "national quality scheme" and "integrated pest management" may play a role. Recent market research [16] showed that only $28 \%$ of respondents from the general public $(n=1004)$ recognized the EU organic food label as a mark for organic products. Large number - 34\% - of respondents mistakably related the sign of Latvian quality scheme "Zaḷā karotīte" or "Green spoon" for organic products. This confusion can also be a cause for the phenomenon that procurers put all three types of certification schemes in one criterion e.g. "it is all the same".

The lack of interest to favour organic food can be also explained by missing policy on the local level: case studies performed in various countries show the importance of clear policy goals and support by local politicians [17]. A study from Italian "high performers" on factors influencing uptake of the "organic food" criterion points out that caterer policy, the pressure from parent committees and beliefs and motivations of responsible public bodies play a role in achieving a higher share of organic food products [14].

\section{Conclusions}

The authors conclude that self-reporting is not an appropriate method to measure implementation level of GPP: a much higher number of public tender documents were selfreported as GPP (54-90 \%) than research showed after closer examination (15\%). However, the screening of tenders is also insufficient to understand the level of implementation i.e. to which extent the green tenders became greener supplies. Clearer quantitative indicators and more frequent supervision could help to measure the real implementation level.

One of the core criterions of the EU GPP guidelines "organic food" is very seldom used in Latvian public procurements for food products ( $4 \%$ as mandatory, and $1 \%$ of award criteria), and there might be several reasons behind that. This means that from a European perspective, where core indicators are used as a benchmark, even less than $15 \%$ of Latvian tenders can be 
regarded as green. Studying this phenomenon more closely could help to understand how to remove the barriers to increase application of this important criterion.

Currently the national regulation on GPP offers quite a large range of the criteria without an indication of their importance. This might lead to a situation where procurers choose the easiest, but less environmentally beneficial options. Reduction of the number of criteria or clear indication of the core set of indicators could help to mitigate this problem. For example, the criterion "no genetically modified organisms" can be omitted since it is already sufficiently addressed by other legislative areas.

\section{ACKNOWLEDGEMENTS}

Authors are grateful to Dr Jānis Brizga, an environmental scientist, for motivation and support to Nora Kibilda-Kinna during her master thesis, which served as a starting injection for the research introduced hereto. Part of the work authors performed thanks to the contract with the Ministry of Environmental Protection and Regional Development of the Republic of Latvia for the support of green public procurement in Latvia.

\section{REFERENCES}

[1] Poore J., Nemecek T. Reducing food's environmental impacts through producers and consumers. Science 2018:360(6392):987-992. https://doi.org/10.1126/science.aaq0216

[2] FAOSTAT. Pesticide use [Online]. [Accessed 24.03.2020]. Available: http://www.fao.org/faostat/en/\#data/rp/visualize

[3] European Commission. Study on "Strategic use of public procurement in promoting green, social and innovation policies". Final report. Directorate-General for Internal Market, Industry, Entrepreneurship and SMEs, PWC. Brussels: Publications Office of the EU, 2017.

[4] McCrudden, C. Using public procurement to achieve social outcomes. Natural resources forum 2004:28(4):257-267. https://doi.org/10.1111/j.1477-8947.2004.00099.x

[5] OECD. Size of public procurement. Government at a Glance 2015. Paris: OECD Publishing, 2015. https://doi.org/10.1787/gov glance-2015-42-en

[6] Cerutti A. K., et al. Carbon footprint in green public procurement: Policy evaluation from a case study in the food sector. Journal of Food Policy 2016:58:82-93. https://doi.org/10.1016/j.foodpol.2015.12.001

[7] De Schutter O. The Power of Procurement Public Purchasing in the Service of Realizing the Right to Food. United Nations Human Rights Council. Briefing Note 08, 2014.

[8] Communication from The Commission to The European Parliament, The Council, The European Economic and Social Committee and The Committee of The Regions. Public procurement for a better environment. Brussels: European Commission, 2008.

[9] Cabinet of Ministers of Republic of Latvia. Regulation No. 353 - Requirements for Green Public Procurement and Procedures for Application. Latvijas Vēstnesis Nr. 129, 30.06.2017.

[10] Commission Staff Working Document. EU green public procurement criteria for food, catering services and vending machines. Brussels: European Commission, 2019.

[11] Lee P. et al. Revision of the EU GPP criteria for Food procurement and Catering services. Luxembourg: Publications Office of the European Union, 2016. https://doi.org/10.2791/099130

[12] Renda A., et al. The uptake of green public procurement in the EU27. Annexes. Centre for European Policy Studies, College of Europe. Brussels: CEPS, 2012.

[13] Polikarpova I., et al. Multi-Criteria Analysis to Select Renewable Energy Solution for District Heating System. Environmental and Climate Technologies 2019:23(3):101-109. https://doi.org/10.2478/rtuect-2019-0082

[14] Filippini R., et al. Sustainable school food procurement: What factors do affect the introduction and the increase of organic food? Journal of Food Policy 2018:76:109-119. https://doi.org/10.1016/j.foodpol.2018.03.011

[15] Pekal A. Market analysis of organic foods in the Nordic and Baltic countries. Copenhagen: Nordic Council of Ministers, 2020.

[16] Survey of recognition of environmental labels in Estonia, Latvia, Lithuania. Unpublished market research. NORSTAT, 2019.

[17] Smith J., et al. Balancing competing policy demands: The case of sustainable public sector food procurement. Journal of Cleaner Production 2016:112:249-256. https://doi.org/10.1016/j.jclepro.2015.07.065 